\title{
How Political Is the Kantian Church?
}

\author{
- Stephen R. Palmquist -
}

\begin{abstract}
Commentators who lament that Kant offers no concrete guidelines for how to set up an ethical community typically neglect Kant's claim in Religion that the ethical state of nature can transform into an ethical community only by becoming a people of God-i.e., a religious community, or "church." Kant's argument culminates by positing four categorial precepts for church organization. The book's next four sections can be read as elaborating further on each precept, respectively. Kant repeatedly warns against using religious norms to control people. Accordingly, he explicitly forbids the true church from adopting any standard form of political governance; it must aim to be radically non-political. Nevertheless, churches organized according to Kant's non-coercive theocratic model contribute something essential to the ultimate political goal of achieving perpetual peace and an end to war: by approaching the ultimate ethical goal (the highest good), the true church offers an antidote to normative fragmentation.
\end{abstract}

Keywords: Immanuel Kant, politics and religion, ethical community, religious freedom, perpetual peace, church and state.

Published online: 4 September 2020

\section{Does Kant give concrete guidelines for organizing a church?}

Commentators on Kant's much-discussed theory of the "ethical community" 1 express frustration that he seems to offer precious little advice as to how we are actually to establish and maintain real, empirical examples of his grand vision. As one of the most erudite representatives of this tendency, for example, Philip Rossi laments in his book, The Social Authority of Reason, that Kant never tells us "the concrete means" for implementing his moral ideal in human societies. ${ }^{2}$ Even if Kant had successfully described such means, Rossi argues, "the dynamics of an emergent globalized culture," which has been manifesting itself in so many ways during the twenty-first century, now call into question "the very possibility of forming a shared intent to social union of the kind

\footnotetext{
Stephen Palmquist

Department of Religion and Philosophy

Hong Kong Baptist University

Kowloon, Hong Kong SAR

China

e-mail: stevepq@hkbu.edu.hk

${ }^{1}$ Kant's technical term, ethische gemeinen Wesen, is also often translated as "ethical commonwealth."

2 See, e.g., Rossi (2005): 9, 60. For my critique of Rossi's book, see Palmquist (2010a). More recently, Rossi (2019) offers a shorter account of the ethical commonwealth that similarly remains at the level of a broad vision, to which I respond in Palmquist (2020).
} 
envisioned by Kant as the basis of an ethical commonwealth." ${ }^{3}$ Not surprisingly, such commentators typically pay little (if any) attention to Kant's theory of the church.

Rossi's portrayal of Kant's position issues a two-sided challenge to anyone who, like me, believes that "Kantian religion"4 serves not merely as an impossible ideal, but also as a set of concrete guidelines for a way of life that we can actually practice in the world today. The first side of the challenge calls for a demonstration that Kant himself does identify "the concrete means" that we may employ in order to bring ourselves closer and closer to realizing the ideal goal of establishing an ethical community. The second side of Rossi's challenge calls for an explanation of how an ideal that is essentially based on a set of ethical norms, as Kantian religion obviously is, ${ }^{5}$ can survive in our contemporary, pluralistic world, wherein the problem of "normative fragmentation" 6 seems to prevent any religious or ethical tradition from attaining anything close to universal acceptance - to say nothing of the ultimate goal that Kant himself repeatedly expressed: perpetual peace. ${ }^{7}$ The purpose of this article will be to demonstrate that in RGV Kant gives us the basic tools we need to meet Rossi's challenge.

Admittedly, some Kant interpreters would view this challenge as a non-issue, because they read Kant's theory of "rational religion" as referring to something that

\footnotetext{
${ }^{3}$ Rossi (2005): 3-4.

${ }^{4}$ As used here, the term "Kantian religion" refers to any human organization that is set up in such a way that it aims to provide an empirical manifestation of what Kant calls "true religion" in his epoch-making work, Religion within the Bounds of Bare Reason (hereafter, RGV). (All quotations from RGV are taken from Palmquist (2016) and cite the volume and page numbers of the Berlin Academy Edition of Kant's works.) Even if those who establish or maintain such an organization know nothing about Kant's philosophy, it might still qualify as "Kantian religion" - e.g., if scholars who do know Kant's theory of religion, upon examining the beliefs, symbols, and rituals of a given religious group, assess the organization's guiding principles as consistent with Kant's basic requirements for authentic religion, as set out in $\$ 2$, below.

${ }^{5}$ I argued in Palmquist (1992) that Kant's theory of religion is not an attempt to reduce religion to morality but to raise morality to the level of religion. While this claim has been well-received by many interpreters over the past three decades, it still requires clarification in some quarters. My non-reductive approach to Kantian religion does not imply that morality is in any way dispensable; rather, I agree with reductionist interpreters that Kantian religion must promote moral improvement. Where I differ is on the question of whether non-moral elements can have a legitimate role to play in this process. Reductionist interpreters typically say that Kant's goal was to rid religion of all non-moral features, whereas my work on Kantian religion over the past 30+ years has focused largely on an effort to demonstrate that Kant allows a very clear and even crucial role for non-moral religious norms, in the form of indirect duties - actions that can empower us to be moral. That is, when (as is often the case) a human being cannot obey the moral law on the sole basis of naked (i.e., bare [bloßen]) reason, Kant's message in RGV is that clothing moral reason with appropriate non-moral norms can be just what human beings need to make the "can" in "ought implies can" into an is. As such, the problem of normative fragmentation (see note 6, below) is profoundly relevant to my interpretation.

${ }^{6}$ Wesley Bergen (2019) highlights the problem of normative fragmentation as a key challenge for Kant's theory of the ethical community. Drawing inspiration (though not the term) mainly from Taylor (1989), Bergen defines "normative fragmentation" (1) as "the condition of finding meaning in one's life according to multiple yet conflicting philosophical frameworks." He takes issue with Alasdair MacIntyre's premature rejection of Kant's position as it relates to this problem. The term itself has been used more by political theorists than by ethicists (see, e.g., Fauchald and Nollknaemper (2012)), but it aptly describes the problem that Rossi (2005) brings to light.

${ }^{7}$ Kant's most detailed statement of this goal comes in his 1795 book, Toward Perpetual Peace. But even in RGV the theme comes up several times: see RGV 6:34, 38, 113, 124.
} 
is so utterly pure that it never has and never could have a concrete historical manifestation - a religion so purely "rational" that it has no place in the empirical world. Douglas McGaughey (2013) adopts this reading of RGV in his critique of my interpretation. Basing his portrayal of my position solely on a one-sided (i.e., non-perspectival) reading of Palmquist (2010b), he takes me to be identifying Kantian religion with historical Christianity $^{8}$ - a position I have never defended - and thus sets up a straw man against which he defends the opposite (but equally implausible) extreme. My actual position is that Kantian religion is closer to a synthesis of McGaughey's two extremes.

True religion for Kant is a rightly ordered synthesis of pure rational (moral) religion and the theology of some historical faith (not necessarily Christianity - though Kant does portray Christianity as the only historical faith so far that had managed to get things right ${ }^{9}$ ): true religion regards morality as the core element of its faith and harnesses the historical tradition as a "vehicle" 10 that brings practitioners to that end goal, whereas false religion reverses this proper order by regarding the historical tradition as essential and the moral improvement of its practitioners as an optional goal. By ignoring this whole question of the proper ordering of the elements and taking Kant (the alleged "pure rationalist") to be wholly unconcerned with anything historical, those who read Kant as McGaughey does could neatly sidestep Rossi's challenge, simply by saying that Kant's philosophy is too pure, too rational to be bothered by anything as messy as the problem of normative fragmentation - a problem that most citizens of the twenty-first century face on a daily basis. This, however, is an easy escape that is not available to anyone who reads Kant's theory of religion as I actually do - that is, as affirming precepts that encourage a lived (i.e., historically manifestable) religious way of life that can empower human beings to fulfil the purely rational/moral ideal that functions as human nature's vocation or "predetermination" (Bestimmung).

What Kant commentators can easily overlook, even those who interpret RGV in a more moderate way than McGaughey does, is that by insisting that we put "bare reason"

\footnotetext{
${ }^{8}$ McGaughey (2013): 155-156 sets out a table listing eleven (mostly accurate) aspects of Kant's pure moral religion and juxtaposes each with a contrasting feature that I allegedly read into Kant's religious system. For example, I supposedly identify Kantian religion with "historical religion based on particular revelation," which is "reduced by Kant to "mere' morality if no Noumenal (divine) perspective," Kantian grace as "a divine gift without an account of the 'ground' of humanity's moral capacity," Kantian Christology as an "exclusive" reference to a "morally perfect individual as the historical archetype of the Logos external to the individual," "[m]oral improvement" as "concerned merely with the individual," and more-all of which constitute a grossly inaccurate account of my perspectival, "affirmative" interpretation of Kant's theory of true religion as a synthesis of rational religion and historical faith that cannot be reduced to mere morality (see Palmquist (1992)), of his view of grace as a divine supplement grounded in the individual's ethical integrity (Palmquist (2010b)), of Christology as symbolic and inclusive of a multiplicity of possible historical instantiations (Palmquist (2012)), and of moral improvement as necessarily culminating in salvation for humanity as a united moral community (e.g., Palmquist (2017)). ${ }^{9}$ For detailed textual evidence defending this claim, see Palmquist (2000), Chapter VIII, entitled "Christianity as the Universal Religion of Mankind."

${ }^{10}$ Kant uses this term in the following passages: RGV 6:106-107, 118, 123n., 135n. In Palmquist (2016) I argue that the entirety of the Third Piece in RGV can be taken as Kant's account of how such a vehicle ought to be organized. Elsewhere Kant also uses the metaphor of rational/moral religion being a "seed" or "kernel" that must be protected and encouraged to sprout and grow by being imbedded in the "shell" of some historical faith.
} 
at the core of our religious lives Kant was setting out to solve the very problem that Bergen identifies - a "monster" that was already rearing its ugly head in Kant's day (cf. RGV 6:23n., 34), inasmuch as any attempt to solve the problem of normative fragmentation by political means only tends to make the problem worse. What causes interpreters such as Rossi to read right past Kant's solution to this problem is that they take Kant's ideal of the moral community to be an essentially political vision, whose purposes religion may help to fulfill in some ways, for those who choose to be religious, but for which religion need not play any essential role in its fulfilment. As I have argued in Palmquist (1994), the view that politics is the core of the Kantian path to peace, religion being a merely optional vehicle for carrying it to fruition, is precisely the opposite of the way Kant actually portrays the proper interaction between religion and politics.

For Kant, the Hobbesian transformation of the juridical state of nature into the juridical civil state is admittedly a prerequisite for the new kind of transformation that Kant introduces in RGV, of the ethical state of nature into the ethical civil state (RGV 6:95-96). Yet, when read in the context of the whole book's overall argument, it becomes clear that we radically evil human beings can fulfil our rational destiny (to live in a world of perpetual peace) only by fulfilling our moral predetermination; and this, Kant argues, is possible only if the ethical community becomes a religious community. ${ }^{11}$ Perhaps as a result of his downplaying of the central role Kant gives to religion in the fulfilment of human destiny, Rossi consistently neglects the implications of this pivotal argument in Division One of RGV's Third Piece, wherein Kant argues that humanity's unique duty to build an ethical community can be fulfilled only by viewing such a community in religious terms, as a "People of God" (see RGV 6:98-100). In §IV, Kant introduces the term "church" to refer to the ethical community that views itself as a people of God; what few interpreters acknowledge is that, after $\S \mathrm{IV}$, "church" becomes Kant's preferred term for the ethical community. ${ }^{12}$

Does Kant offer concrete guidelines for organizing the church? If so, what are they? And if not, is this an oversight, or is it part of the book's strategic design? I will begin to answer these questions in $\$ 2$ by examining the four precepts that Kant explicitly introduces in §IV of Division One of RGV's Third Piece, as guidelines for anyone who sets out to construct an authentically religious organization. In §3 I will first examine

${ }^{11}$ For my full defense of this claim, see my detailed interpretation of RGV 6:96-100 in Palmquist (2009), where I call this Kant's "religious argument" for God's existence. For an early version of the same way of interpreting this passage in RGV, see Palmquist (2000): 167-169.

12 As I point out in Palmquist (2016): 267, when Kant first introduces "church" as a technical term in $\S I V$, he portrays it initially as a manifestation of the "ethical community" (used three times in that section); for the remainder of RGV Kant then uses "ethical community" only a handful of times (RGV 6:106, 126, 152, 153), whereas he uses "church" roughly 200 times. As a result, commentators who tend to stick close to Kant's text find themselves compelled to use "church" more frequently - much as they might prefer to avoid such a loaded religious word - while those who tend to depend on broad overviews of the text, such as Rossi (who claims in Rossi (2019): 38-39 that Kant simply "identifies" these two terms), typically use Kant's preferred word only rarely. (For example, Rossi (2005) uses "church" only a few times, in passing $[56,61,99]$.) Whereas the ethical community is an ideal presented to us by reason and could (in principle) be secular, the true Kantian church must be religious, for its ability to empower human beings to live together in peace stems directly from its supersensible postulate (i.e., its conviction that a moral God has founded and sustains the community). 
and interpret the implications of the paragraph that immediately follows Kant's listing of the four precepts, where he explicitly comments on the type of political structure churches should adopt. I will then draw on evidence from throughout RGV to show that Kant does propose concrete rules and policies for organizing a "true" (i.e., Kantian) church. Finally, I shall conclude the paper by explaining in $\$ 4$ how churches that are organized in such a way that they approximate this ideal model can contribute to the task of achieving peace, not only in the political realm, with its constant threat of war, but also in the ethical realm, as a direct antidote to normative fragmentation.

\section{Kant's Four Precepts for Organizing a True ("Militant") Church}

Kant's above-mentioned argument in the early pages of RGV's Third Piece is well known and often repeated: his creative idea that, since ethics and politics are respectively inward and outward aspects of the same moral reality, Hobbes' political theory must have a metaphorical counterpart in ethics, needs no further elaboration here. What does need highlighting is that in the very next section of RGV (i.e., in §IV of Division One) Kant portrays the task of founding an ethical commonwealth as one that is necessarily a partnership between human beings and God. In short, Kant says God must found "the invisible church" and ought therefore to be trusted as the inward guide of all its members and as the guarantor of their unity. The invisible church is "a bare idea ... serving as an archetype for any such government to be founded by human beings," while the actual, outwardly observable (and hence, political) body that must be founded by us humans is the "visible church" (RGV 6:101) - a term that refers to any of the various empirical manifestations of religious organizations that seek to embody the rational ("invisible") ideal.

Kant often refers to the various types of visible church that human beings create as historical forms of religion; he clarifies in RGV 6:105 that his main focus in RGV is on the matter that properly functions as the (moral) core of religion. Somewhat counter-intuitively, then, historical religion concerns visible church "forms" [Form], while pure rational religion concerns invisible church "matter" [Materie]. Immediately after introducing this visible-invisible distinction, Kant moves directly to a concise statement of the four precepts that make up the "invisible" side of this equation -i.e., the concrete material of any true religion. As the invisible church is the conveyor of rational/moral religion, the precepts that constitute its boundary conditions ${ }^{13}$ have an a priori status:

${ }^{13}$ The term Kant uses most often to refer to these four ideal "requirements" or "marks" of the true church is "Grundsätze" (used three times in RGV 6:101-102 alone), the same term used in the first Critique for what English-speaking Kant scholars usually call the four "principles" of pure understanding that guide us in formulating any empirical cognition that is to be scientifically legitimate. In Palmquist (2016): 531, I argue that, because Kant's term Princip has a distinct meaning and obviously needs to be translated as "principle," English Kant commentators should use a different term for Grundsätze. I chose "precepts" because it suggests what I take to be a main feature of all such boundary conditions: they reside in reason, not in the world as such, and thus their applicability is not absolute, but depends on the standpoint we are adopting. That is, just as the first Critique's Grundsätze are put aside in the second Critique, because the standpoint changes from theoretical to practical reason, so also the Grundsätze in RGV are applicable only to those who aim to construct an ethical community as a people of God (i.e., a church). 
they are necessary conditions for the possibility of any empirical religion that is to present itself as a representative of what Kant calls the "true church" or "true religion."

It should come as no surprise to anyone aware of Kant's reliance on architectonic reasoning that when he sets out to enumerate and explain the rational, a priori precepts that convey the matter of the true church, he follows the pattern set by the categories that he had introduced and defended in the first Critique: quantity, quality, relation, and modality. In a nutshell, the true church consists of any empirical religious organization that aims to keep the following precepts as its fundamental guideposts:

1. Universality. The quantity of the true church is one.

2. Integrity. ${ }^{14}$ The church's quality aims at its members' moral edification.

3. Freedom. The relation of church members must be free of coercion both (a) inwardly (i.e., members will not exercise control over each other) and (b) outwardly (i.e., the church and political state will operate independently).

4. Unchangeability. The modality of the church's constitution is (a) necessary, in the sense that these four basic precepts will never change, while also being (b) possible, in the sense that all other aspects of church governance are always open to change.

The common impression that Kant never fleshes out the implications of these four precepts arises largely from the fact that interpreters have failed to notice that each of the next four sections of RGV focuses, in turn, on one of them. The following summary of those four sections sketches how each section elaborates on one of the four a priori requirements for the true church:

1. Universality: $\S \mathrm{V}$ offers concrete guidelines for pluralistic ecumenism, arguing that any historical faith that seeks to embody the true church must strive to preserve the one true religion as its material (moral) core. That is, regardless of how one visible church's traditions (i.e., its beliefs, symbols, and rituals) may differ from those promoted by another visible church, if both organizations share the basic goal of aiming to illustrate these four precepts through their traditions, then both should be regarded as belonging equally to the one universal (invisible) church.

2. Integrity: §VI offers concrete guidelines for interpreting whatever text(s) a particular church regards as its holy scripture; regardless of what text may be chosen, the church's pastors, theologians, and other educators must always interpret it in such a way that the members' integrity (i.e., their moral improvement) will remain at the forefront of the church's operational purpose.

3. Freedom: §VII explains with a concrete example how to ensure that church doctrine will have genuinely saving power: church leaders must allow the laity

\footnotetext{
${ }^{14}$ Kant's term, Lauterkeit, is usually translated as "purity." But doing so encourages one of the most serious errors English readers have made in interpreting Kant's theory of religion: interpreting this "purity" as if it is identical to the purity that lies at the core of Kant's Critique of Pure Reason. In the latter book, "pure" translates reinen, which refers not to moral integrity but to an absence of sensible content. This conflation of two very different German terms has led some readers to assume that Kant's moral theory in general, and his theory of religion in particular, are antipathetic toward our physical nature. Yet, as I argue throughout Palmquist (2016), Kant's theory of religion consistently displays a profound respect for the importance (and natural goodness) of the body.
} 
to respond freely to the "antinomy of faith"15 that plagues all doctrine, rather than binding the people to a delusion that would rob doctrine of its ability to activate practical (moral, freedom-enhancing) faith. Only when the people are freed from any such political controls, Kant argues toward the end of this section, can "the kingdom of God" become real on earth.

4. Unchangeableness: Division Two of the Third Piece takes authentic Christianity as an illustration of the true church and contrasts it with both Judaism and various forms of historical Christianity, as examples of false churches. The key difference Kant thereby illustrates is the way different historical faiths treat the fourth requirement: true visible churches allow their historical tradition to evolve while holding tight to the four precepts, whereas false visible churches downplay or even reject one or more of the first three precepts (i.e., they regard their own particular historical tradition as the one and only true faith, they regard non-moral duties as more important than moral ones, and/ or they employ various outward tools of coercion to force their members to obey, often through the agency of the state) and instead portray something changeable in their tradition as so absolutely important that disagreement can justify religious war.

Having elaborated significant details illustrating each of these four a priori precepts, Kant devotes the Fourth Piece to an even more concrete explanation of how to distinguish between the way the true church and false churches serve God.

Before we examine (in \$3) Kant's application of these four precepts to the task of discerning how political the true church is to be, let us consider briefly the further distinction, borrowed from traditional Lutheran theology and traceable at least as far back as St. Augustine, which Kant introduces near the beginning of §VII. Before discussing the nature of "sanctifying faith," Kant points out that, because visible churches are bound to have some dogma and "since concerning historical dogmatics one can never avoid conflict," the visible church is and always will be the "church militant" (RGV 6:115); yet, if it is a true church, it will look forward to "the prospect of breaking out, eventually, into the unchangeable and all-unifying church triumphant!" Is Kant here condoning religious war as a prelude to the triumph of true religion? Far from it! An easily unnoticed theme that runs through the pages of RGV is that false religion promotes violence whereas true religion promotes peace. The problem Kant is here acknowledging is that, prior to the eschatological "end of all things" (the title of the essay Kant published in 1794, shortly after completing the second edition of RGV), the visible church will inevitably manifest normative fragmentation. ${ }^{16}$ That is, genuinely religious people are bound to disagree over the dogmatic content of religion just as much as they disagree over whether the political right or the political left will pave the way to a better future; Kant's point in §VII is that, if a particular church upholds the four precepts as the rational content of its faith, then such conflict can be philosophical and thus healthy. What unites us together and thereby points the way toward the ideal that Kant (echoing the Bible) calls "the kingdom of God

\footnotetext{
${ }^{15}$ See Palmquist (2016): 303-318; cf. RGV 6:116, 119.

16 See note 6, above.
} 
on earth" is our reliance on the genuine content provided by the precepts: universality, integrity, freedom, and unchangeableness.

One might argue that these four precepts are themselves normative and that, as such, religious people are bound to disagree on these just as much as they tend to disagree on other dogmatic issues. But in the next section I shall argue that Kant thinks otherwise. On what grounds? Because any organization that adopts these four precepts as its organizational norm will be (paradoxically) taking something fundamentally formal and a priori as the basis for its material content. And doing this is equivalent to eclipsing the tendency every human organization naturally has to identify itself through its external, political norms ${ }^{17}$ Or, to put it more succinctly, the true Kantian church must, as we shall see, establish itself outwardly on a political norm that paradoxically insists on being non-political (i.e., inwardly focused).

\section{What Is the Role of Politics in the (Visible) Church?}

As if he had himself posed the question serving as the title of this section, Kant devotes the very next paragraph - following his initial summary of the four precepts that must guide any visible church that seeks to conform to the invisible aim of an ideal, rational religion - to a clear statement of the difference between the visible church's way of being political and the standard forms of political system that characterize the juridical civil state. In the first sentence, he uses the explicitly political term, Staat, for the first time to refer to the ethical community (RGV 6:102): "Therefore, an ethical community, regarded as a church, i.e., as a bare representative of a nation [Staat $]^{18}$ of God, actually has no structure [that is] similar, according to its precepts, to the political one." In §III, where he had argued that the ethical community must become a "people of God [Volke Gottes]" (RGV 6:98-99), Kant had explicitly clarified that the Jewish concept of such a "people," as a "theocracy" governed through political coercion (RGV 6:99-100), is not what he has in mind. His use of "Staat" at this point suggests that, whereas the invisible church constitutes the actual "nation of God," each distinct visible church must acknowledge itself to be but a "bare representative" - elsewhere he uses the term "vehicle [Vehikel]"19 - of the ideal, invisible church and, as such, must eschew any and all political structuring.

Lest there be any doubt about the essentially non-political nature of the Kantian (visible) church, Kant devotes the second sentence of this concluding paragraph of §IV

\footnotetext{
${ }^{17}$ Here it would be instructive to consider empirical correlates to Kant's project of founding an empirical religion based on purportedly universal rational principles. Indeed, various attempts have been made in recent decades to discover a universal ethic by canvassing the world's religious and ethical traditions in search of a univocal core of normative belief that transcends the all-too-evident normative fragmentation. Due to limits of space, however, I cannot pursue this topic further in the present article. ${ }^{18}$ When Kant first introduces the notion of an ethical community in RGV, he starts (at RGV 6:95) by distinguishing between the political or "juridical civil state" and the "ethical civil state." Much potential confusion is created for English readers by this use of "state," which translates Zustand, a German term that refers not to a political entity but to a situation. (Thus, Hobbes" phrase, "state of nature," refers to a natural situation, not to a discrete political entity governed by nature.) To avoid the likely conflation of technical terms that results from this idiosyncrasy of translation, I translate Kant's Staat as "nation." See Palmquist (2016): 530 for a fuller justification of this novel convention.

${ }^{19}$ See note 10 , above.
} 
to a step-by-step rejection of the ways most existing (Christian) churches have tended to adopt one or another of Aristotle's three forms of political system: kingship, aristocracy, and polity. ${ }^{20}$ In particular, none of the following church structures is entailed by the four precepts of the true church (RGV 6:102): the "monarchic (under a pope or patriarch)," as illustrated by Roman Catholic and Orthodox forms of Christianity; the "aristocratic (under bishops and prelates)," as illustrated by forms of Christianity such as the Lutheran and Reformed traditions; and the "democratic (as of sectarian illuminates)," as illustrated by Christian churches that adopt a decentralized congregationalist form of government, such as (most) Baptists and Pentecostals. ${ }^{21}$ Instead of imitating one of these standard secular approaches to political organization, the political system adopted by the true church that Kant has in mind will be comparable to:

the structure of a household (family) under a common - though invisible-moral father, insofar as his holy son, who knows his father's will and simultaneously stands in blood relationship with all the members of the household, stands in his father's place in disclosing his will to them more closely; [and] the members therefore honor the father in him and thus enter with one another into a voluntary, universal, and continuing unification of heart (RGV 6:102).

Obviously alluding to Jesus, Kant here acknowledges that the true church must have a political structure, but suggests that this structure will exhibit three key features: (1) the principal authority figure will be invisible (cf. "God the father," in Christian tradition); (2) a human being deemed to be holy will be honored as God's visible representative (cf. Jesus as "God the son"); ${ }^{22}$ and (3) "the members" will govern their relationships with each other through an inwardly legislated law of love - i.e., through a "continuing unification of heart."

Although Kant does not devote any specific section of Religion to a fuller discussion of the (non-)political structure of the true church, he does comment briefly on this feature of his theory in numerous passages. Of these, perhaps the most direct example comes in Division Two of the Third Piece (RGV 6:130-131): Kant gives eight examples (each introduced with the word "how") of historical Christian churches perpetrating all manner of (mostly political) abuses in the name of true religion. Thus, instead of serving as channels of increased freedom, doctrines of the church were taken as "blind supersti-

${ }^{20}$ For a summary of Aristotle's three political systems as they relate to the theme of religion and politics, see Palmquist (1993): Chapter 1.

${ }_{21}$ For reasons that will become clear later in this section, when we discuss the role of control in false forms of religion, Kant makes a similar point at RGV 6:180: regardless of whether a church "structure" is "monarchic or aristocratic or democratic ... its constitution under all these forms yet is and always remains despotic."

${ }^{22}$ In Section Two of the Second Piece (RGV 6:78-84), Kant interprets Jesus' voluntary suffering and death as having conquered the inward sovereignty of evil in the hearts of human beings who follow his path, even though the fact that he had to die illustrates that evil retains its outward "dominion" over the hearts of human beings. (For good accounts of this argument, see Chignell (2010) and Rossi (2019): 50.) That the religious victory over evil is primarily inward helps to explain why the political structure of an authentic religious organization must be love-oriented. For a detailed defense of this point, see Palmquist (1993): Chapter 7. 
tion" and used as tools of coercion that "weighed down the people with heavy fetters"; likewise, "with a hierarchy thrusting itself upon free human beings, the terrible voice of orthodoxy rose from the mouth of pretentious, exclusively called interpreters and divided the Christian world into embittered parties." In Eastern Christianity "the nation itself occupied itself with statutes of faith of the priests and with the priestery," such that it "inevitably had to fall prey in the end to foreign enemies" (RGV 6:130), while in Western Christianity, the pope became so powerful that "the civil order along with the sciences (which sustain it) was shattered and made powerless by a pretended vicar of God" who "ruled over and chastised kings like children by means of the magic wand of his threatened excommunication" (RGV 6:131), as a result of which "both Christian parts of the world ... were attacked by barbarians..." What makes these examples of false religion is, above all else, the fact that the religious leaders insisted on usurping political power, thereby inciting the kings "to foreign wars (the Crusades) depopulating another part of the world, to antagonism among one another, to the rebellion of subjects against those in authority over them and to bloodthirsty hatred against their differently minded fellow comrades of one and the same universal so-called Christianity" (RGV 6:131). Indeed, Kant concludes by noting wryly that even more "violent eruptions" would have occurred, if it were not for the "political interest" of those instigating the problems; for "the root of this unrest ... lies hidden in the precept of a despotically commanding church faith" (ibidem). Clearly, then, one of the main distinguishing features between true and false ways of being religious is that the true church and its leaders are deeply non-political (in the sense of not using coercive techniques to force others to comply, though as we shall see, not in the sense of having no impact on the prevailing secular government), while false religion attempts to use religious forms to exercise political control over others (both within the church and in relation to various secular government bodies).

One of the main tools of political coercion employed by false expressions of religion is violence. Thus, Kant illustrates his theory regarding the moral interpretation of scriptures by pointing out that when the Bible (or any religious scripture) tells stories that seem to condone violence, we must interpret these not as justifying war or other uses of violence between human beings, but should rather offer a spiritual interpretation (RGV 6:110n.), whereby such passages encourage us to wage a metaphorical war on those tendencies in ourselves that keep us from living a fully moral life. Similarly, as early as the First Piece Kant explicitly warns against treating the exhibition of mindless cruelty during war as a sign of bravery (RGV 6:33n.), and in Section Two of the Second Piece he portrays Jesus as waging spiritual war against Satan. ${ }^{23}$ In Division Two of the Third Piece he then argues that anyone with a conscience should not accept violence in political or religious policies, as this will hamper the development of the "divine predispositions" within us (RGV 6:134), which alone can lead us into a life of moral improvement, and thereby eventually lead to a peaceful society.

A related insight regarding Kant's view of the (non-)political nature of the true church's organization can be gained by examining his use of the term Gewalt - one of the five terms Kant uses that are often translated as "power." To distinguish between

${ }^{23}$ See note 22, above. 
these terms, I translate each with a different English word; for Gewalt I use "control." 24 Early in the first Preface of Religion (RGV 6:5) Kant notes that one of the key problems with human morality is that we cannot control the results of our actions - a theme that crops up several times throughout the First Piece. ${ }^{25}$ He then goes on to argue that government censorship of publications concerning religion (which had been enforced by the new king for the past few years) should not apply to what philosophers publish, because the philosopher's reliance on "criticism" provides sufficient control (RGV 6:8). That this was a sensitive topic for Kant is shown by the fact that, shortly after Kant published the second edition of RGV in 1794, the king's minister formally censored him for violating the relevant edict. ${ }^{26}$ Clearly, the personal context in which Kant found himself, as he wrote his book on the nature of authentic religion, must have deeply influenced his thinking on the extent to which the true church should get involved in politics.

In Section Two of the Second Piece Kant examines the struggle between evil and good in terms of the biblical story of Jesus overcoming Satan's control (or "dominion") over human beings. He views the biblical account as an answer to the question why God did not simply "control" Satan by "annihilat[ing] at its beginning the kingdom that he [Satan] intended to found" (RGV 6:79). Identifying evil with the "legal" system that rightfully exercises coercive measures in human societies, Kant points out that Jesus was put to death precisely because he revolted against this "foreign dominion (which has control)" on earth (RGV 6:81-82). He explicitly rejects the view that Jesus' aim "was not moral but merely political" (RGV 6:81n.) - namely, "to topple the government of the priests and, with supreme worldly control, put himself in its place." Hence, the result of Jesus' death was "the breaking of [the evil principle's] control," so that it can no longer hold "against their will" the good-hearted people who (as he goes on to argue in the Third Piece) establish the visible church on earth. In other words, even though Jesus' ministry appeared to fail, by ordinary, external (political) standards, it succeeded, once we interpret it through spiritual eyes - the eyes also required to "see" the invisible church.

One way of describing Hobbes' above-mentioned theory of the "state of nature" is that in this pre-civilized situation, no public authority has "control" over the people (RGV 6:97n.); the problem, Kant here explains, is that the lack of all external (political) controls inevitably leads to a "state of war" (RGV 6:96, 97n.) - a "continual wounding of the rights of all others" (RGV 6:97n.) - because each person is likely to do whatever they think is right, even if it hurts others. ${ }^{27}$ Similarly, in the ethical state of nature, obeying the moral law is "under our control" (RGV 6:98); but when it comes to the special duty to build an ethical community, "we cannot know whether ... it is also under our control." This is precisely the reason Kant argues that we can establish the possibility of the ethical community only by regarding it as religious. ${ }^{28} \mathrm{God}$, as the being who can control the founding of the invisible kingdom of virtue, must exist in order for this duty to be

\footnotetext{
${ }^{24}$ See Palmquist (2016): 450n., 519.

${ }^{25}$ See, e.g., RGV 6:29n., where Kant defines "passion" as "an inclination that precludes self-control."

${ }^{26}$ See Palmquist (2016): 3-4, 23.

${ }^{27}$ See Palmquist (2017).

${ }^{28}$ See note 11 , above.
} 
feasible. ${ }^{29}$ Hence, although Kant does not use "Gewalt" when defining the third precept that must guide the true church (RGV 6:102), he clearly implies that the twofold freedom defined by this precept is a freedom from being controlled by one's fellow churchgoers or by the political regime. Thus, in a poignant passage in Division Two Kant argues that the government is, in any case, unable to control what counts most in human life-one's thoughts - but warns that religion can be dangerous precisely because its leaders do often attempt (and sometimes even succeed) to control the laity's innermost thoughts: "what the secular supreme potentate cannot do, the spiritual potentate can indeed: namely, prohibit even thought, and really also prevent it; indeed, it can impose such a coercion, namely the prohibition so much as to think differently from what it prescribes, even on its mighty superiors" (RGV 6:133n.)..$^{30}$

Kant's key distinction in the Fourth Piece, between true and false ways of serving God, can be interpreted as a distinction between two ways of understanding the role of political coercion (or control) in a church. Thus, in Part One, Kant says it is "an absurd arrogance" to attempt "through spells ... things that are in fact not under our control" (RGV 6:159n.). Lest his reader think he is referring only to literal attempts to do magic, Kant uses an explicitly political example: he approvingly notes that "the wise teacher" (i.e., Jesus) tells his followers that the practice of taking oaths in court is "from the evil one" (cf. Matthew 5:37). Similarly, in the General Comment to the Second Piece, Kant had argued that a belief in miracles may be acceptable in rational religion, as long as one does not interpret it as a way of controlling God (RGV 6:88). The General Comment to the Fourth Piece makes a similar point: Kant questions the legitimacy of his four chosen examples of "means of grace" (i.e., prayer, churchgoing, baptism, and communion) but without rejecting them absolutely; they are delusory only when taken as a way of controlling how God distributes grace (RGV 6:192). For Kant, salvation is not and cannot be under the control of human beings, as it is God's prerogative alone; what is under our control, as we have seen, is our ability to choose to live our lives according to the good principle. As such, Kant offers reinterpretations of each of the four traditional means of grace, arguing that rituals such as prayer, churchgoing, baptism, and communion can be a legitimate part of a true church's service of God, if they indirectly motivate us to be good.

In the General Comment to the Third Piece, Kant interprets the "trinity" as a moral concept, arising out of "a threefold superior control" of the type found "in a juridically civil nation" (RGV 6:140), except that we view "this threefold quality of the moral sovereign of the human race ... as unified in one and the same being" (i.e., God), whereas in its political manifestation such control "would necessarily have to be distributed among three different subjects." In the Fourth Piece Kant likewise expresses deep suspicion regarding the need for clergy in the true church, for the clergy tend to

\footnotetext{
${ }^{29}$ Kant's portrayal of God's role in relation to the church directly parallels his argument in the Second Piece, regarding God's relation to individuals. On the one hand, Kant repeatedly insists that each of us must freely choose to do good in the phenomenal world, if any genuine goodness (virtue) is to be attributed to us; yet on the other hand, he depicts God's holy (noumenal) judgment as being capable of making up for the inevitable deficiencies that prevent any given individual's lifestyle from achieving perfection. The same goes for God's role in founding the church: in no sense does God's "founding" of the invisible church replace humanity's obligation to emerge from the ethical state of nature.

${ }^{30}$ See also note 31.
} 
exercise control over the people, as symbolized by the special garments they wear in most historical faiths (RGV 6:165) - a tendency Kant derides by coining a derogatory term that Pluhar aptly translates as "priestery." Even in Protestant churches that dispense with clerical robes, Kant observes, the clergy typically "want to be regarded as the unique called interpreters of a Holy Scripture," and thereby "they transform service of the church ... into a domination of its members" (ibidem). They do this, he argues, by classifying "statutes of faith" as a type of "constitutional law," thus allowing them to "dispense with reason and even, ultimately, with scriptural scholarship, because [the clergy alone], as the only authorized guardian and interpreter of the will of the invisible lawgiver, exclusively has the authority to administer the prescription of faith and thus, provided with this control, need not convince but only order" (RGV 6:180). ${ }^{31}$

RGV is filled with comments such as the foregoing, where Kant admonishes religious leaders of his day to resist the temptation to think that the religious path to peace requires them to usurp political power. If there is any message that shines forth from the pages of RGV, it is that when religion (a fundamentally inwardly oriented human phenomenon) gets mixed up in politics (a fundamentally outwardly oriented human phenomenon), the good intentions of the religious will surely backfire, and evil is bound to result.

Admittedly, Kant does foreshadow, as early as the First Piece, that the hope to move from war to "the state of an eternal peace" must be "based on a federation of peoples [constituted] as a world republic" (RGV 6:34) - a claim he fleshes out in much greater detail two years later, in his groundbreaking work, Perpetual Peace. ${ }^{32}$ Whereas in the latter work Kant provides a step-by-step procedure for the way governments can prepare the way for peace among nations, RGV leaves little doubt that the ultimate requirement for actually establishing peace is not political but religious: if human beings cannot help each other find ways of controlling our propensity to evil, then no amount of political maneuvering will bring lasting peace. Thus, Division One of the Third Piece concludes by proclaiming that "eternal peace" will come to the human race only when the invisible dominion of the "good principle" establishes humanity as a community:

This, then, is the work - unnoticed by human eyes but progressing constantly - of the good principle, of establishing for itself, in the human race as a community according to laws of virtue, a potency and a kingdom that maintains the victory over evil and that, under its dominion, assures the world of an eternal peace (RGV 6:124).

\footnotetext{
${ }^{31}$ Kant goes on to add that, because all non-clergy count as "laity," the leader of a false church "ultimately rules the national regime, not exactly through control, but through influence of the minds [and] also, in addition, through pretense of the benefit that the regime is allegedly supposed to be able to draw from an unconditional obedience to which a spiritual discipline has accustomed even the thinking of the people" (RGV 6:180).

${ }^{32}$ Kant further foreshadows the argument of Perpetual Peace at RGV 6:34n., where he says war can be regarded as "a certain mechanistic progression of nature in terms of purposes that are not their [the peoples'] purposes, but purposes of nature." The "monster" of "universal monarchy," once "it has devoured all neighboring nations, eventually disintegrates on its own and, through insurrection and discord, divides into many smaller nations"; unless "a republic of free confederated peoples" can be formed, these smaller nations will then "start the same game over again, in order by all means to keep war (this scourge of the human race) from ceasing."
} 
Authentic religion makes room in society for just the sort of inwardly legislated, fully mutual moral brotherhood that is required in order for lasting peace to arise; for as Rossi aptly puts it: the "distinctive role [of religion] in human efforts to secure the order of peace as the highest political good ... is to constitute a social space of human interaction that ... empowers the enactment of the full moral mutuality that is requisite for enacting an enduring condition of peace." 33

\section{How Does the Church Contribute to Humanity's Political Predetermination?}

If the true (Kantian) church is to uphold at its core a political constitution that requires its chief aim to be non-political (i.e., to focus first and foremost on promoting an inward moral revolution in every person), and thus to promote solutions to political problems by cooperating instead with the providential guidance of a moral God, then can it contribute in any meaningful way to what most people would regard as an essentially political goal - establishing eternal peace? Rossi portrays Kant's vision of the ethical community as one that can be manifested in a religious way but (contrary to my argument here) is not necessarily religious. ${ }^{34}$ In defending this reading, he points out ${ }^{35}$ that, at one point in Metaphysics of Morals (RL 6:355), Kant uses the exact German title he had used for RGV, but replaces "Religion" with "Rechtslehre." When Kant there states that "establishing universal and lasting peace constitutes not merely a part of the doctrine of right, but rather the entire final end of the doctrine of right within the bounds of bare reason" (my translation), he appears to be pointing beyond the doctrine of right to the doctrine of virtue as this "final end." ${ }^{36}$ If so, then this supports my contention that politics must work together with religion in order for eternal peace to occur. But in precisely what way do they work together? Just how political must the visible church be in order for humanity to fulfill the political goal of establishing eternal peace?

That Kant refers to both religion and the doctrine of right as being "within the bounds of bare reason" is not accidental. For political systems, like historical religions, serve to clothe the inward core of bare (religious/moral) reason. That is, just as in RGV pure religious faith (or moral religion) constitutes the inner core of true religion, while historical faiths (i.e., non-moral religious traditions) constitute its outer vehicle or clothing, so also in Metaphysics of Morals the politics of right occupies the book's outer vehicle while the ethics of good constitutes its inner core. As we saw in the previous two

\footnotetext{
${ }^{33}$ Rossi (2019): 45.

${ }^{34}$ For my detailed response to Rossi's claim that Kantian religion is an optional approach to establishing a political goal, see Palmquist (2020).

${ }^{35}$ Rossi (2019): 330.

${ }^{36}$ Taylor (2010): 8-9 helpfully points out that, although Kant says in the Doctrine of Right (RL 6:350) that this final end is "unachievable," he also says that "continual approximation to it ... can certainly be achieved." Taylor persuasively argues (ibidem: 9-13) that perpetual peace is part of (and a subsidiary to) the ultimate end of the highest good. The key difference, he argues, is observability: "Perpetual peace is an effectively observable condition of the highest good" (ibidem: 13), whereas our own virtue is not transparently observable, even to ourselves. This is why, for Kant, "political community acts as a precondition for ethico-religious forms of community" (ibidem: 2): publicity, as the main criterion for good politics, is an achievable ideal, whereas its ethical equivalent, "transparency," requires the postulates of God and immortality in order to be achievable.
} 
sections, historical faiths inevitably take on some external (political) form, but the closer they come to exhibiting a non-political way of organizing themselves politically, the more authentically they represent the moral ideal. This is what I have elsewhere described as a "non-coercive" version of "theocracy." ${ }^{37}$

Seán Molloy is one of the few commentators on Kant's political philosophy who recognizes that, if we take Kant's arguments in RGV's Third Piece at face value, then far from supporting Rossi's vision of an ethical community being established through the implementation of externally legislated, enlightened political policies, which may or may not be assisted by religious organizations that catch this quintessentially political vision, Kant's own political vision is thoroughly and inextricably dependent on an essentially theocratic faith in the invisible (rational) government of God. "God's government is the capstone of Kant's philosophical doctrine of religion and is extremely important in relation to his moral theory, [international relations] theory, and the resolution of the question of human destiny ... The cement that binds the concepts of Kant's [theory of international relations] together is religious." 38 The secular Kant, stripped of his theocratic politics, has few (if any) viable tools to help us face the problem of normative fragmentation. For as Molloy adds: “in Kant's system, human beings without faith in God ... are ultimately reduced at best to the abderite condition of being in a perpetual state of bustling folly and at worst are doomed to ultimate and unredeemed destruction." 39 Secular interpreters of Kant will search in vain for a viable Kantian solution to the ultimate political problems we face in the modern world.

In a passage from §VI of Division One of the Third Piece that has previously been translated almost incomprehensibly, due to a number of ambiguities in Kant's German, Kant can be read as offering a rare, practical illustration of just how political a church ought to be. As I argue in Palmquist (2016), a plausible but accurate translation of RGV 6:113, where Kant is in the process of explaining the government's responsibility toward religious organizations, is:

If the regime only takes care that there is no lack of scholars and of men standing in good repute in terms of their morality, who administer the whole of church affairs [and] to whose consciences it entrusts this management, then it has done everything that its duty and authority require. But that the regime itself should carry these clerics into the school and [have them] deal with scholarly controversies (which, provided they are not carried on from pulpits, leave the church-public in utter peace) [-this] is an imposition that the public cannot make on the lawgiver without immodesty, because it is beneath his dignity. ${ }^{40}$

\footnotetext{
37 See Palmquist (2017). For a detailed defense of the claim that such non-coercive theocracy is the political system presented in the Bible, see Palmquist (1993), where I also argue that what normally goes by the name "theocracy" is actually its opposite-more appropriately called "ecclesiocracy." The latter (i.e., false theocracy) occurs when human beings assume they are capable of controlling God or acting on God's behalf. Kantian (and biblical) theocracy, by contrast, assumes what Kant (in RGV 6:139) calls "faith in the cooperation or arrangement, by a moral ruler of the world, through which alone this purpose [i.e., the highest good] is possible."

${ }^{38}$ Molloy (2013): 331.

39 Ibidem: 333.

40 Palmquist (2016): 299.
} 
If I have correctly translated the ambiguous second sentence, then Kant is obviously alluding to his own current situation, where a cleric (Wöllner) had been appointed by the king as the censor to watch over scholars publishing controversial texts relating to religion. Kant's response to this situation aptly illustrates how to apply his second and third precepts for the authentic visible church: the government's sole duty is to ensure that good-hearted, well-educated people are appointed to positions of leadership in the church, so that integrity of conscience will be the church's enduring focus; beyond this, the government should leave the church free to do its good work in peace and the church (including church leaders, the clerics) should likewise avoid taking up political positions in the name of the church or involving the laity in purely scholarly debates.

For Kantian religion, peace is the ultimate goal, but the process for achieving peace necessarily involves struggle -in particular, the struggle to resist the temptation to resolve moral problems through political coercion. Instead, empowering the laity with an active conscience is crucial to the success of Kantian religion; indeed, the main text of RGV ends, in Part Two of the Fourth Piece, with a section extolling conscience (rather than clerics, who are in effect religious politicians) as the laity's true guide in all matters of faith. Earlier, Kant had cautioned against a false "peace of conscience" (RGV 6:38) among those who remain unaware of their own evil-heartedness and thus see no need for the inward struggle that for Kant inevitably characterizes the genuinely religious person. In discussing the last of three "difficulties" that arise for any religious concept of divine assistance (i.e., grace), he argues that such inward struggles constitute a "pain" (RGV 6:74) that the converted person can appropriately regard as the (divine) punishment for his or her pre-conversion evil. ${ }^{41}$ Does this way of understanding Kantian religion, as a moral struggle undertaken by us human beings in the faith that God will somehow cooperate with and guide our best efforts to be good, provide any solace to those who are vexed by the problem of normative fragmentation, which, as we saw in $\$ 1$, is so deeply ingrained in the modern world?

Kant's focus on creating moral community between individuals who are willing to support each other in a mutual struggle to be good is the key to understanding how he thinks a visible church should respond to the political world here and now, before the final realization of the "church triumphant," when all normative fragmentation will be brought into perfect harmony in one "all-unifying" whole (RGV 6:115). In other words, in Kantian religion the church militant has the difficult task of entering into the arena of politics and implanting or (where the seeds already exist) nourishing community - an inwardly focused reality - whereas secular politics on its own must choose between tolerating normative fragmentation and implementing restrictive policies to enforce normative uniformity. Kant's vision of rational religion calls us to regard our normative differences as grist for the mill of making a future hope (i.e., the invisible church triumphant) into a present reality. Unlike standard theories of politics, which depend (like Aristotle's influential political theory) on looking at the past and assessing which of the existing political systems suits our present situation the best, Kant asks us to look to the future, imagine a political reality that does not (or may not) yet exist because it is

$\overline{{ }^{41}}$ For a detailed discussion of this claim, see Palmquist (2016): 202-207. 
grounded on four fundamentally non-political precepts, and then work to bring that moral transformation of politics to pass in the world today. ${ }^{42}$ Kant's speculations regarding the possibility of a new kind of church, based on rational religion, that serves as an engine for political change precisely through its ability to unite humanity even in the presence of normative fragmentation, are, as Molloy rightly puts it, "exercises in prophesy" ${ }^{43}$ they constitute "divination based in reason." ${ }^{44}$

In conclusion, the foregoing interpretation of Kantian religion, as having the ultimate political goal of transforming politics by dispensing with it, agrees with Howard Williams' answer to the question whether religion or politics is more important for Kant: "The highest political good and the highest moral good can, [Kant] thinks, only be achieved simultaneously. Nature and individuals will only live in harmony together in world society when that world society is a world community." ${ }^{45}$ Williams goes on to affirm that what is needed is not just any world community, but an inner awakening that must create, in Kant's terminology, a religious community. Williams (1996) states more explicitly Kant's reliance on an ultimately religious solution: "Only by an act of divine grace for which there is no empirical evidence can we hope finally to attain eternal peace." ${ }^{46}$ Williams himself finds Kant's appeal to the need to achieve "a gradual triumph over the darker side of human nature" to be implausible; instead, he argues, politicians should find pragmatic ways of channeling human anger and aggression through activities that are less harmful than war, such as games and sport. As Molloy has rightly argued, however, to reject Kant's theological solution to the political problem of war and human aggression (as well as the problem of normative fragmentation) is to render his position wildly implausible. Either the Kantian church, with its faith in divine-human cooperation as the non-political path to overcoming the dark side of human nature,

\footnotetext{
${ }^{42}$ See Molloy (2013): 324.

${ }^{43}$ Ibidem.

${ }^{44}$ Molloy adds: "Kant works forwards from what is the case and backwards from what ought to be the case in order to argue the eventual achievement of a peaceful world" (ibidem: 325). Molloy quotes from Part Two of Kant's 1798 work, The Conflict of the Faculties, to provide persuasive textual evidence that Kant saw this transformation of world society as making a difference in people's actual political interactions, not merely in their visible-church relationships. Molloy (2017) is a more thoroughgoing assessment of how Kant's "almost mystical metaphysics" (ibidem: 28) relates to contemporary work (including allegedly Kantian applications such as that of John Rawls) to international relations theory. He persuasively argues that Kant's frequent appeals to providence are not anomalies but strike to the core of an essentially theological understanding of how human beings ought to involve themselves in politics. (On the latter theme, see Palmquist (1993).) Williams (2018) presents Molloy as affirming all of this not in order to defend it, but rather, along the lines of Carl Schmitt's political theology, to drown out Kant's insightful analysis with a "nihilist caveat" (ibidem: 691). While Molloy's concluding reminder of the atheistic assumptions of contemporary international relations scholarship (Molloy (2017): 164) might have the implicit effect of undermining Kant's position, Molloy's explicit caveat is: "I am not endorsing Schmitt's political theology" (ibidem: 27). In any case, Palmquist (2019) shows how Kant's metaphysics is indeed "almost mystical," arguing that Critical philosophy has implications for mysticism that directly correspond to its implications for metaphysics. For an excellent demonstration that Kant's political philosophy is diametrically opposed to Rawls' attempt to keep metaphysics out of politics (relegating religious belief and moral convictions to the status of a side-show that is tolerated by but not determinative of the political sphere), see Wong (2018).

${ }^{45}$ Williams (1983): 268.

${ }^{46}$ Williams (1996): 14.
} 
is plausible and worthy of our assent, or we should forgo all references to "invisible" principles, accept normative fragmentation as an unsolvable predicament, and place our trust in the (pre-Kantian) Enlightenment illusion that we human beings know what is best for ourselves, and that the perpetual war of party politics can deliver it - a solution that seems to Kant to be far more presumptuous than a humble attempt to cooperate with providence. ${ }^{47}$

\section{References}

Bergen W.W. (2019), Moralizing the Civilized: A Kantian Approach to the Problem of Normative Fragmentation, M.Phil. thesis in philosophy at the Chinese University of Hong Kong.

Chignell A. (2010), "The Devil, the Virgin, and the Envoy: Symbols of Moral Struggle in Religion II.2," [in:] Religion innerhalb der Grenzen der bloßen Vernunft, O. Höffe (ed.), Akademie Verlag, Berlin: 111-130.

Fauchald O.K., Nollkaemper A. (eds.) (2012), The Practice of International and National Courts and the (De-)Fragmentation of International Law, Hart Publishing, Oxford.

Kant I. (1793/2009), Religion within the Bounds of Bare Reason, trans. W.S. Pluhar, Hackett, Indianapolis (revised translation in Palmquist (2016)).

McGaughey D. (2013), "Historical and Pure Religion: A Response to Stephen Palmquist," The Journal of Religion 93 (2): 151-176.

Molloy S. (2013), “An 'All-Unifying Church Triumphant'. A Neglected Dimension of Kant's Theory of International Relations," The International History Review 35 (2): 317-336.

Molloy S. (2017), Kant's International Relations: The Political Theology of Perpetual Peace, University of Michigan Press, Ann Arbor.

Palmquist S. (1992), “Does Kant Reduce Religion to Morality?,” Kant-Studien 83 (2): 129-148.

Palmquist S. (1993), Biblical Theocracy: A Vision of the Biblical Foundations for a Christian Political Philosophy, Philopsychy Press, Hong Kong.

Palmquist S. (1994), "'The Kingdom of God Is at Hand!' (Did Kant Really Say That?)," History of Philosophy Quarterly 11 (4): 421-437.

Palmquist S. (2000), Kant's Critical Religion: Volume Two of Kant's System of Perspectives, Ashgate, Aldershot; republished (2019), Routledge, New York.

Palmquist S. (2009), “Kant's Religious Argument for the Existence of God - The Ultimate Dependence of Human Destiny on Divine Assistance," Faith and Philosophy 26 (1): 3-22.

Palmquist S. (2010a), "Philip J. Rossi's The Social Authority of Reason: Kant's Critique, Radical Evil and the Destiny of Humankind," Kant-Studien 101 (1): 127-131.

Palmquist S. (2010b), "Kant's Ethics of Grace: Perspectival Solutions to the Moral Difficulties with Divine Assistance," The Journal of Religion 90 (4): 530-553.

Palmquist S. (2012), “Could Kant's Jesus Be God?," International Philosophical Quarterly 52 (4): 421-437.

Palmquist S. (2016), Comprehensive Commentary on Kant's Religion within the Bounds of Bare Reason, John Wiley \& Sons, Chichester.

Palmquist S. (2017), “Kant's Model for Building the True Church: Transcending 'Might Makes Right' and 'Should Makes Good' through the Idea of a Non-Coercive Theocracy," Diametros 54: 76-94.

\footnotetext{
${ }^{47}$ I would like to thank two anonymous referees for valuable feedback on a previous draft of this article, which led to significant improvements in this final version.
} 
Palmquist S. (2019), Kant and Mysticism: Critique as the Experience of Baring All in Reason's Light, Lexington Books, Lanham.

Palmquist S. (2020), “Humanity's Moral Trajectory: Rossi on Kantian Critique,” Philosophia (forthcoming).

Rossi P.J. (2005), The Social Authority of Reason: Kant's Critique, Radical Evil, and the Destiny of Humankind, SUNY Press, New York.

Rossi P.J. (2019), The Ethical Commonwealth in History: Peace-Making as the Moral Vocation of Humanity, Cambridge University Press, Cambridge.

Taylor C. (1989), Sources of the Self: The Making of Modern Identity, Harvard University Press, Cambridge MA.

Taylor R.S. (2010), "Kant's Political Religion: The Transparency of Perpetual Peace and the Highest Good," The Review of Politics 72 (1): 1-24.

Williams H. (1983), Kant's Political Philosophy, Basil Blackwell, Oxford.

Williams H. (1996), International Relations and the Limits of Political Theory, St. Martin's Press, New York.

Williams H. (2018), “Sean Molloy Kant's International Relations," Kantian Review 23 (4): 689-693.

Wong S. (2018), The Roles of the Moral and the Political in the Philosophies of Kant and Rawls, PhD dissertation in Philosophy at Hong Kong Baptist University. 